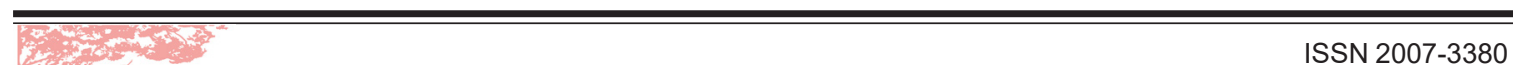

\title{
Eclosion inhibition of Haemonchus contortus eggs with two extracts of Caesalpinia coriaria fruits
}

\section{Inhibición de la eclosión de huevos de Haemonchus contortus con dos extractos de frutos de Caesalpinia coriaria}

\author{
Olmedo-Juárez, A. ${ }^{2}$ (D) De Jesús-Martínez, X. ${ }^{1}$, Rojas-Hernández, S. ${ }^{1}$ (D), \\ Villa-Mancera A. ${ }^{3}$ (D) Romero-Rosales, $T^{1}{ }^{1}$ (D), Olivares-Pérez, J. ${ }^{\text {* }}$ (iD.
}

\begin{abstract}
${ }^{1}$ Universidad Autónoma de Guerrero, Programa de Posgrado Maestría en Ciencias Agropecuarias y Gestión Local, Carretera Iguala-Tuxpan, Guerrero, México. 'Instituto Nacional de Investigaciones Forestales Agrícolas y Pecuarias, Centro Nacional de Investigación, Disciplinaria en Salud Animal e Inocuidad, Carretera Federal Cuernavaca- Cuautla $N^{\circ}$ 8534/Col. Progreso C.P. 625550, Jiutepec, Morelos, México / A.P. 206- CIVA. ${ }^{3}$ Facultad de Medicina Veterinaria y Zootecnia - Benemérita Universidad Autónoma de Puebla, Puebla, México.
\end{abstract}

Cite this paper/Como citar este artículo: Olmedo-Juárez, A., De Jesús-Martínez, X., RojasHernández, S., Villa-Mancera A., Romero-Rosales, T., Olivares-Pérez, J. (2022). Eclosion inhibition of Haemonchus contortuseggs with two extracts of Caesalpinia coriaria fruits. Revista Bio Ciencias 9 e1121. doi: https://doi.org/10.15741/revbio.09.e1121



\section{A B S T R A C T}

Haemonchus contortus is a gastrointestinal parasite of small ruminants. The objective of the study was to evaluate the effect of the acetonic and ethanolic extracts of the Caesalpinia coriaria fruits legume on the egg eclosion inhibition (EEI) of $H$. contortus in small ruminants. For this effect, it was evaluated at different concentrations of the extracts (acetonic: 20.0, 10.0, 5.0, 2.5, 1.2 and $0.6 \mathrm{mg} / \mathrm{mL}$ ), (ethanolic: $6.15,3.12,1.56$ and $0.78 \mathrm{mg} / \mathrm{mL}$ ), and methanol $4 \% \mathrm{v} / \mathrm{v}$ in distilled water as negative control and ivermectin $0.5 \%$ as positive control, were used. The inhibitory effect data were analyzed with a completely randomized design by analysis of variance using the general linear model and the Tukey test $(p<0.05)$; the lethal concentrations $\left(\mathrm{LC}_{50}\right.$ and $\mathrm{LC}_{90}$ ) were estimated by the Probit analysis of the statistical analysis systems (SAS) program. The inhibitory

\section{Article Info/Información del artículo}

Received/Recibido: December $13^{\text {th }} 2020$.

Accepted/Aceptado: January $05^{\text {th }} 2022$.

Available on line/Publicado: January $26^{\text {th }} 2022$.

\section{RE S U M E N}

Haemonchus contortus es un parasito gastrointestinal de los pequeños rumiantes. El objetivo del estudio fue evaluar el efecto del extracto acetónico y etanólico de frutos de la leguminosa Caesalpinia coriaria sobre la inhibición de la eclosión de huevos (EEI) de $H$. contortus en pequeños rumiantes. Por éste efecto se evaluó a diferentes concentraciones de los extractos (acetónico: 20.0, 10.0, 5.0, 2.5, 1.2 y $0.6 \mathrm{mg} / \mathrm{mL}$ ), (etanólico: 6.15, 3.12, 1.56 y $0.78 \mathrm{mg} /$ $\mathrm{mL}$ ), y metanol al $4 \% \mathrm{v} / \mathrm{v}$ en agua destilada fue utilizada como control negativo e ivermectina $0.5 \%$ como control positivo. Los datos del efecto inhibidor se analizaron con un diseño completamente al azar mediante análisis de varianza utilizando el modelo lineal general y la prueba de Tukey $(p<0.05)$; las concentraciones letales $\left(L_{50}\right.$ y $\left.L_{90}\right)$ se estimaron mediante el análisis Probit del programa de sistemas de análisis estadístico (SAS). Los efectos inhibitorios de los extractos dependieron de la concentración, donde la actividad inhibitoria fue comparativamente similar al control positivo a las dosis de $1.2 \mathrm{mg} / \mathrm{mL}$ para el extracto acetónico (AE) y $0.78 \mathrm{mg} / \mathrm{mL}$ para el extracto etanólico (EE), $(p<0.0001)$. Las LC $_{50}$ fueron 
effects of the extracts depended on the concentration, where the inhibitory activity was comparatively similar to the positive control doses of $1.2 \mathrm{mg} / \mathrm{mL}$ for the acetonic extract (AE) and $0.78 \mathrm{mg} / \mathrm{mL}$ for the ethanolic extract (EE), $(p<0.0001)$. The $\mathrm{LC}_{50}$ were $\mathrm{AE}=0.23 \mathrm{mg} / \mathrm{mL}$ and $\mathrm{EE}=$ $0.014 \mathrm{mg} / \mathrm{mL} ; L C_{90} A E=1.04 \mathrm{mg} / \mathrm{mL}$ and $E E=0.14 \mathrm{mg} / \mathrm{mL}$. The results indicate that the EEI of the extracts elaborated with the $C$. coriaria fruits in acetonic and ethanolic solvent have inhibitory activity against $H$. contortus eggs eclosion, nevertheless, requires further investigations as antiparasitic for oral use in animals.

\section{KEY WOR D S}

Caesalpinia coriaria, Haemonchus contortus, parasite, eggs.

\section{Introduction}

Parasitism is one of the main problems that affect small ruminants, and in this group, gastrointestinal nematodes (GIN) are the most important cause of mortality in sheep and goats in the tropics of Mexico (Delgado, A. et al., 2016; Zapata et al., 2016; Canul-Ku et al., 2012). H. contortus is a gastroenteric nematode that parasitizes the abomasum of ruminants (sheep, goats and cattle) and is epidemiologically the most important with $70 \%$ prevalence in tropical regions (Olivares et al., 2012; Ehsan et al., 2020) This parasite is the most pathogenic (Baltrusis et al., 2020), it feed on blood, injury the abomasal epithelium and clinically causes epithelium inflammation, emaciation, anemia and hypoproteinemia with losses of up to 500 $\mathrm{mL}$ of blood/day, submandibular edema, drooping of the productive parameters (production of wool, milk and meat), and in many cases death of infected animals (Eshan et al., 2020). The frequent use of anthelmintic for the parasites control has been one of the causes that has led to the resistance development of these microorganisms (LacaMegyesi et al., 2020). The parasites are a problem from a biological and economic point of view, especially when the inadequate use of chemical dewormers is abused, this has promoted the development of the anthelminthic resistance (Muñiz-Lagunes et al., 2015). Kaplan \& Vidyashankar (2012) reported resistance of $H$. contortus to ivermectin, moxidectin, levamizole and albendazole in $76 \%, 24 \%$, $98 \%$ and $54 \%$ of the studied goat and sheep herds; to
$\mathrm{AE}=0.23 \mathrm{mg} / \mathrm{mL}$ y $\mathrm{EE}=0.014 \mathrm{mg} / \mathrm{mL} ; \mathrm{LC}_{90} \mathrm{AE}=1.04 \mathrm{mg} /$ $\mathrm{mL}$ y $E E=0.14 \mathrm{mg} / \mathrm{mL}$. Los resultados indican que la $E E I$ de los extractos elaborados con los frutos de C. coriaria en disolvente acetónico y etanólico tienen actividad inhibitoria contra huevos de $\mathrm{H}$. contortus, sin embargo, requiere de mayores investigaciones como antiparasitario para su uso vía oral en animal.

\section{PALABRAS CLAVE}

Caesalpinia coriaria, Haemonchus contortus, parásito, huevos.

\section{Introducción}

El parasitismo es uno de los principales problemas que afectan a los pequeños rumiantes, y en este grupo, los nematodos gastrointestinales (GIN) son la causa más importante de mortalidad en ovejas y cabras en el trópico de México (Delgado, A. et al., 2016; Zapata et al., 2016; Canul-Ku et al., 2012). H. contortus es un nematodo gastroentérico que parasita el abomaso de los rumiantes (ovinos, caprinos y bovinos) y es epidemiológicamente el más importante con una prevalencia del $70 \%$ en las regiones tropicales (Olivares et al., 2012; Ehsan et al., 2020). Éste parásito es el más patógeno (Baltrusis et al., 2020), se alimenta de sangre, lesiona el epitelio abomasal y clínicamente provoca inflamación del epitelio, emaciación, anemia e hipoproteinemia con pérdidas de hasta $500 \mathrm{~mL}$ de sangre/día, edema submandibular, caída de los parámetros productivos (producción de lana, leche y carne), y en muchos casos muerte de animales infectados (Eshan et al., 2020). El uso frecuente de antihelmínticos para el control de parásitos ha sido una de las causas que ha propiciado el desarrollo de resistencias de éstos microorganismos (LacaMegyesi et al., 2020). Los parásitos son un problema desde el punto de vista biológico y económico, especialmente cuando se abusa del uso inadecuado de desparasitantes químicos, esto ha promovido el desarrollo de la resistencia a los antihelmínticos (Muñiz-Lagunes et al., 2015). Kaplan \& Vidyashankar (2012) reportaron resistencia de $\mathrm{H}$. contortus a ivermectina, moxidectina, levamizol y albendazol en $76 \%, 24 \%, 98 \%$ y $54 \%$ de los rebaños de cabras y ovejas estudiados; a tetrahidropirimidinas y lactonas macrocíclicas (Baltrusis et al., 2020).

El impacto del parasitismo por GIN ha motivado el desarrollo de investigaciones en medicina alternativa, como el uso de 
tetrahydropyrimidines and macrocyclic lactones (Baltrusis et al., 2020).

The impact of parasitism by GIN has motivated the development of investigation in alternative medicine, such as the use of biological agents (fungi and hematophagous mites) (Pérez-Pérez et al., 2014; Von de - Fernex et al., 2015; Olmedo et al., 2014; García-Ortiz et al., 2015) and medicinal plants or extracts of tree leaves with nematicidal properties of use in ruminants (León-Castro et al., 2015 Olivares et al., 2012; Carvalho et al., 2012). Manuel-Pablo et al. (2020) reported that the supply of a diet with $4.5 \%$ tannins from the $C$. coriaria fruits in goats; they had a daily consumption of $45 \mathrm{~g}$ of the secondary compounds without negative effects on health, weight gain and feed conversion of the animals. The arboreal legume C. coriaria Jacq. Willd, is commonly known as "Cascalote", is widespread in the Tierra Caliente region of Guerrero and contains a high variety of secondary metabolites such as tannins, gallic acid, and flavonoids (Sánchez-Carranza et al., 2017), gallotannins (methyl gallate) and their derivatives were also identified (De Jesús-Martínez et al., 2018). The objective of the study was to evaluate the acetonic and ethanolic extracts from $C$. coriaria fruits against $H$. contortus eggs.

\section{Material and Methods}

Vegetative material corresponded to $C$. coriaria dried fruit $(5000 \mathrm{~g})$ were collected in march in the Tierra Caliente region of Guerrero, Mexico, located at $18^{\circ} 20^{\prime} 30^{\prime \prime}$ NL and $10039^{\prime} 18^{\prime \prime} \mathrm{WL}$, which were brought to total dryness through of a forced-air heater at $40{ }^{\circ} \mathrm{C}$. Subsequently they were subjected to a milling with a Mini Wiley Mill, to obtain a particle size of $1 \mathrm{~mm}$.

\section{Preparation of acetonic and ethanolic extracts}

Each acetone and ethanol extracts were elaborated separately preparing a solution of $300 \mathrm{~g}$ of dried fruits of C. coriaria suspended in $2000 \mathrm{~mL}$ of the solvents, during $72 \mathrm{~h}$, at room temperature, to extract polar secondary compounds and intermediate polarity. Then the liquid solutions of the extracts were filtered with different filters separately in the following order, first gauze, then cotton and finally filter paper, the residual solvents were removed by distillation under reduced pressure with the help of a rotary evaporator (Buchi R-114) at $60{ }^{\circ} \mathrm{C}$, and finally, they were dried by Lyophilization processes (Labconco FreeZone $-105{ }^{\circ} \mathrm{C}$ ) to obtain the semi-solid extracts. The agentes biológicos (hongos y ácaros hematófagos) (PérezPérez et al., 2014; Von de - Fernex et al., 2015; Olmedo et al., 2014; García-Ortiz et al., 2015) y plantas medicinales o extractos de hojas de árboles con propiedades nematicidas de uso en rumiantes (León-Castro et al., 2015; Olivares et al., 2012; Carvalho et al., 2012). Manuel-Pablo et al. (2020) informaron que el suministro de una dieta con $4.5 \%$ de taninos de los frutos de $C$. coriaria en cabras; tuvieron un consumo diario de $45 \mathrm{~g}$ de los compuestos secundarios sin efectos negativos sobre la salud, el aumento de peso y la conversión alimenticia de los animales. La leguminosa arbórea C. coriaria Jacq. Willd, comúnmente conocido como "Cascalote", está muy extendido en la región de Tierra Caliente de Guerrero y contiene una gran variedad de metabolitos secundarios como taninos, ácido gálico y flavonoides (Sánchez-Carranza et al., 2017), también, fueron identificados los galotaninos (galato de metilo) y sus derivados (De Jesús-Martínez et al., 2018). El objetivo del estudio fue evaluar los extractos acetónicos y etanólicos de frutos de $C$. coriaria contra huevos de $H$. contortus.

\section{Material y métodos}

El material vegetal correspondió a frutos secos de C. coriaria $(5000 \mathrm{~g})$, fueron recolectados en marzo en la región de Tierra Caliente de Guerrero, México, ubicada a $18^{\circ} 20^{\prime} 30^{\prime \prime} \mathrm{NL}$ y $10039^{\prime} 18^{\prime \prime} \mathrm{WL}$, los cuales fueron llevados a sequedad total a través de un calentador de aire forzado a $40^{\circ} \mathrm{C}$. Posteriormente se sometieron a una molienda con un Molino Mini Wiley, para obtener un tamaño de partícula de $1 \mathrm{~mm}$.

\section{Preparación de extractos acetónico y etanólico}

Cada uno de los extractos de acetona y etanol, fueron elaborados por separado preparando una solución de $300 \mathrm{~g}$ de frutos secos de C. coriaria suspendidos en $2000 \mathrm{~mL}$ de los solventes, durante $72 \mathrm{~h}$, a temperatura ambiente, con el fin de extraer compuestos secundarios polares y de polaridad intermedia. Luego se filtraron las soluciones líquidas de los extractos con diferentes filtros por separado en el siguiente orden, primero gasa, luego algodón y finalmente papel filtro, los disolventes residuales se eliminaron por destilación a presión reducida con la ayuda de un rotavapor (Buchi R-114) a $60^{\circ} \mathrm{C}$, y finalmente se secaron mediante procesos de Liofilización (Labconco FreeZone $-105^{\circ} \mathrm{C}$ ) para obtener los extractos semisólidos. Los extractos secos sin disolvente ( $36 \mathrm{~g}$ ) se almacenaron a $-40{ }^{\circ} \mathrm{C}$ hasta su uso en los bioensayos in vitro. 
solvent-free dry extracts $(36 \mathrm{~g})$ were stored at $-40{ }^{\circ} \mathrm{C}$ until their use in the in vitro bioassays.

\section{Biological material}

\section{Obtaining Haemonchus contortus eggs}

The $H$. contortus eggs were used obtained of the feces from an ovine experimentally infected with infective larvae $\left(L_{3}\right)$ of the parasite (strain INIFAP, 350 $\mathrm{L}_{3} / \mathrm{kg}$ of $\mathrm{BW}$ of the animal). The eggs were concentrated through the passage in different sieves $(200,100,75$ and $37 \mu \mathrm{m}$ in diameter) and by density gradients in $40 \%$ sucrose solution.

\section{Eggs eclosion inhibition (\% EEI)}

Eight 96-well microtiter plates were used. The treatments were acetonic and ethanolic extracts at different concentrations $(20,10,5,2.5,1.2$ and $0.6 \mathrm{mg}$ $/ \mathrm{mL}$ ) and $(6.15,3.12,1.56$ and $0.78 \mathrm{mg} / \mathrm{mL}), 4 \%$ methanol as a negative control and ivermectin injectable solution (5 mg / mL; Ivomec® Pour ON Boehringer Ingelheim laboratory) as a positive control. Fifty $\mu \mathrm{L}$ of an aqueous suspension containing $100 \pm 150 \mathrm{H}$. contortus eggs were placed in each well. Subsequently, aliquots of $50 \mu \mathrm{L}$ of the extracts and controls were added, having a final volume of $100 \mu \mathrm{L}$ per well. The plates were incubated by 48 hours at a temperature of $28^{\circ} \mathrm{C}$, with $100 \%$ humidity (at an incubator Ecoshel model Cl80). The egg eclosion process was stopped by adding $10 \mu \mathrm{L}$ of $5 \%$ lugol solution. Finally, a total count of eggs or larvae of each well was performed and the EEI percentage was determined by the following formula: \% $\mathrm{EEI}=[$ (number of eggs) $/$ (number of larvae + number of eggs)] * 100 .

\section{Statistical analysis}

The data were analyzed under a completely randomized design, with the following statistical model: $Y_{i j}=\mu+T_{i}+\xi_{i j}$; where: $Y_{i j}=$ eclosion inhibition; $\mu=$ general mean; $T_{i}=$ effect of the extracts and controls $\xi_{i}=$ the random error of the treatment. The difference between means was compared with the Tukey test ( $p$ $<0.05)$. In addition, minimum $\left(\mathrm{LC}_{50}\right)$ and maximum $\left(\mathrm{LC}_{90}\right)$ lethal concentrations were determined using the PROBIT procedure of the SAS statistical package (SAS 2002).

\section{Material biológico}

\section{Obtención de huevos de Haemonchus contortus}

Se utilizaron huevos de $H$. contortus obtenidos de las heces de un ovino infectado experimentalmente con larvas infecciosas $\left(\mathrm{L}_{3}\right)$ del parásito (cepa INIFAP, $350 \mathrm{~L}_{3} / \mathrm{kg}$ de BW del animal). Los huevos se concentraron a través del paso en diferentes tamices $(200,100,75$ y $37 \mu \mathrm{m}$ de diámetro) y por gradientes de densidad en solución de sacarosa al $40 \%$.

\section{Inhibición de la eclosión de huevos (\% EEI)}

Fueron utilizadas ocho placas de microtitulación de 96 pocillos. Los tratamientos fueron extractos acetónico y etanólico a diferentes concentraciones $(20,10,5,2.5,1.2$ y $0.6 \mathrm{mg} / \mathrm{mL})$ y $(6.15,3.12,1.56$ y $0.78 \mathrm{mg} / \mathrm{mL})$, metanol al $4 \%$ como control negativo e ivermectina solución inyectable (5 mg / mL; Ivomec $®$ Pour ON laboratorio Boehringer Ingelheim) como control positivo. Fueron colocados $50 \mu \mathrm{L}$ de una suspensión acuosa que contenía $100 \pm 150$ huevos de $H$. contortus en cada pocillo. Posteriormente se agregaron alícuotas de $50 \mu \mathrm{L}$ de los extractos y controles, teniendo un volumen final de $100 \mu \mathrm{L}$ por pocillo. Las placas se incubaron por 48 horas a una temperatura de $28^{\circ} \mathrm{C}$, con $100 \%$ de humedad (en una incubadora Ecoshel modelo $\mathrm{Cl}-80$ ). El proceso de eclosión de huevos se detuvo agregando $10 \mu \mathrm{L}$ de solución de lugol al $5 \%$. Finalmente, se realizó un recuento total de huevos o larvas de cada pocillo y se determinó el porcentaje de EEI mediante la siguiente fórmula: \% EEI = [(número de huevos $) /$ (número de larvas + número de huevos)] ${ }^{*} 100$.

\section{Análisis estadístico}

Los datos fueron analizados bajo un diseño completamente al azar, con el siguiente modelo estadístico: $Y_{i j}=\mu+T_{i}+\xi_{i j}$; donde: $Y_{i j}=$ inhibición de la eclosión; $\mu=$ media general; $T_{i}=$ efecto de los extractos y controles; $\xi_{i}=$ el error aleatorio del tratamiento. La diferencia entre medias se comparó con la prueba de Tukey $(p<0.05)$. Además, se determinaron las concentraciones letales mínima $\left(\mathrm{LC}_{50}\right)$ y máxima $\left(\mathrm{LC}_{90}\right)$ utilizando el procedimiento PROBIT del paquete estadístico SAS (SAS 2002).

\section{Resultados y Discusión}

Los resultados obtenidos en el estudio evidenciaron que los extractos de los frutos de esta 


\section{Results and Discussion}

The results obtained in the study showed evidence that the extracts of the fruits of this arboreal legume have inhibitory effects on the eclosion of $\mathrm{H}$. contortus eggs. In the percentages of $\mathrm{EEI}$, the effects were close to $100 \%$ at the concentration doses of 2.5 and $3.12 \mathrm{mg} L$ of the acetonic (Figure 1) and ethanolic (Figure 2) extracts respectively, this means that both extracts used effectively inhibited the eclosion of eggs to the interrupt their development. Figure 3 shows the images with the readings of the eggs after their incubation with the different treatments, the images $3 \mathrm{~A}, 3 \mathrm{~B}$ and $3 C$ showed the high eclosion of eggs to $L_{1}$ larvae that were observed when they were incubated with the negative controls (methanol at $4 \%$ and $\mathrm{H}_{2} \mathrm{O}$ ). The $3 \mathrm{D}, 3 \mathrm{E}$ and $3 \mathrm{~F}$ images showed the remaining eggs that were inhibited by exposure to the $C$. coriaria fruit extracts. Poné et al. (2011) reported that the active compounds in the extracts penetrate the envelope (cuticle) of the egg and prevent its development and/or paralyze the larvae of the first embryonic stage. Delgado-Nuñez et al. (2020) reported an interruption of embryonic development and a $30 \%$ reduction in the cell mass and shell of the egg. In addition, some eggs showed irregular edges and deformations that produced a wrinkled surface appearance.

Ademola et al. (2011), Zebre et al. (2017) when using an acetonic solvent observed that tannins extracted from leguminosa arbórea tienen efectos inhibidores sobre la eclosión de huevos de $H$. contortus. En los porcentajes de EEI, los efectos fueron cercanos al $100 \%$ a las dosis de concentración de 2.5 y $3.12 \mathrm{mg} / \mathrm{mL}$ de los extractos acetónico (Figura 1) y etanólico (Figura 2) respectivamente, esto significa que los extractos utilizados inhibieron efectivamente la eclosión de los huevos al interrumpir su desarrollo. En la Figura 3 se muestran las imágenes con las lecturas de los huevos después de su incubación con los diferentes tratamientos, las imágenes $3 \mathrm{~A}, 3 \mathrm{~B}$ y $3 \mathrm{C}$ mostraron la alta eclosión de huevos a larvas $\mathrm{L}_{1}$ que se observaron cuando se incubaron con los controles negativos (metanol al $4 \% \mathrm{y} \mathrm{H}_{2} \mathrm{O}$ ). Las imágenes 3D, 3E y 3F mostraron los huevos remanentes que fueron inhibidos por la exposición a los extractos de frutos de C. coriaria. Pone et al. (2011) informaron que los compuestos activos en los extractos penetran la envoltura (cutícula) del huevo e impiden su desarrollo y/o paralizan las larvas de la primera etapa embrionaria. Delgado-Nuñez et al. (2020) informaron de una interrupción del desarrollo embrionario y una reducción del $30 \%$ en la masa celular y la cáscara del huevo. Además, algunos huevos mostraron bordes irregulares y deformaciones que produjeron una apariencia de superficie arrugada.

Ademola et al. (2011), Zebré et al. (2017) al utilizar un solvente acetónico observaron que los taninos extraídos de Cassia alata y Acacia raddiana, respectivamente, fueron responsables de la inhibición de la eclosión de huevos y la inducción de mortalidad

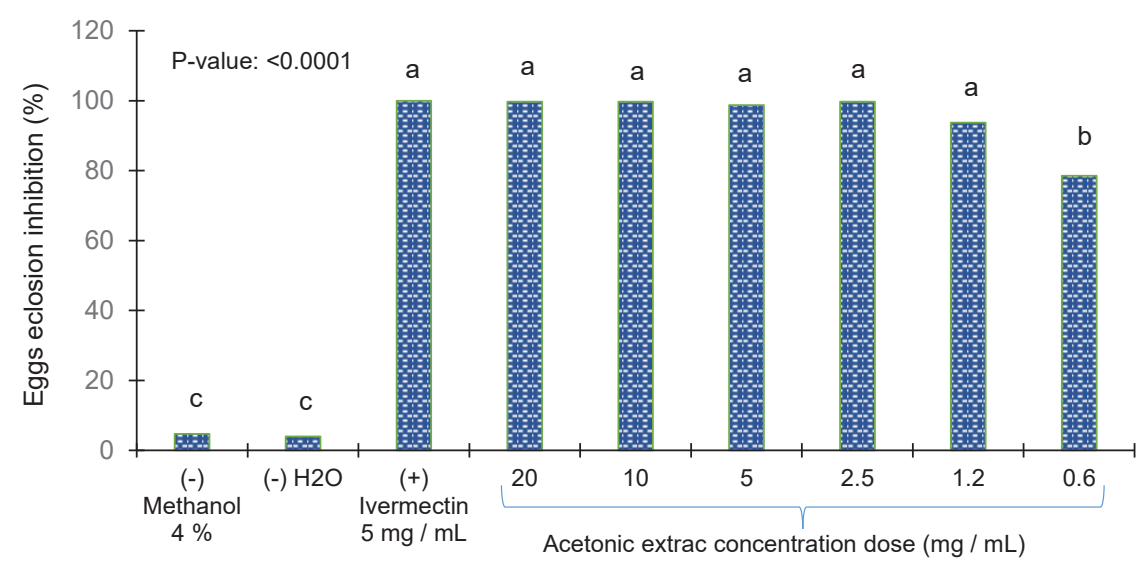

Figure 1. Eggs eclosion inhibition of $\boldsymbol{H}$. contortus exposed to acetonic extract elaborated with $C$. coriaria fruits (abc different literals eclosion inhibition differed between treatments)

Figura 1. Inhibición de la eclosión de huevos de $H$. contortus expuestos al extracto acetónico elaborado con frutos de $C$. coriaria (abcdiferentes literales, la inhibición de la eclosión difirió entre tratamientos) 


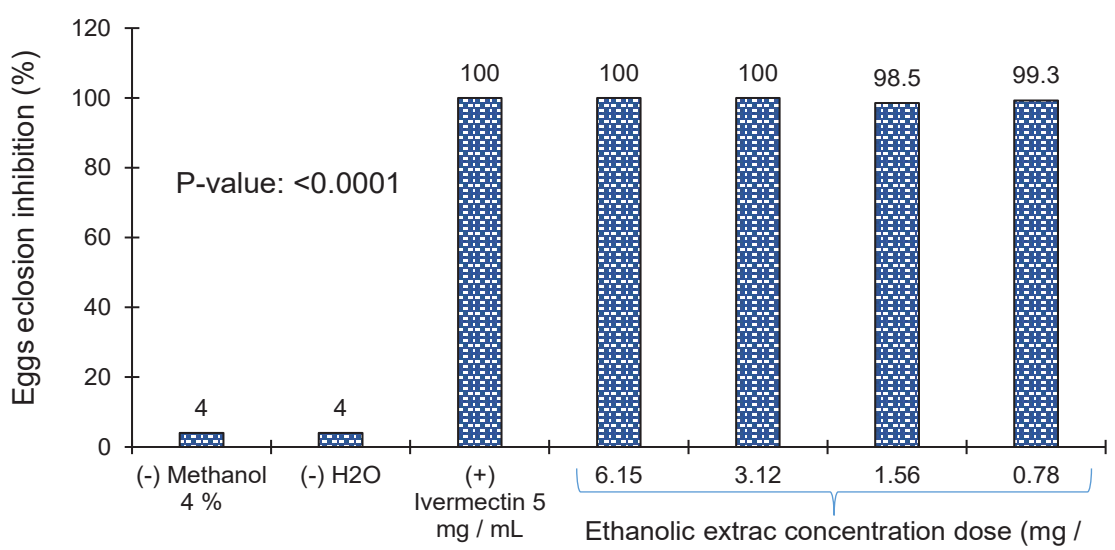

Figure 2. Eggs eclosion inhibition of $\boldsymbol{H}$. contortus exposed to ethanolic extract elaborated with $C$. coriaria fruits (abc different literals eclosion inhibition differed between treatments).

Figura 2. Inhibición de la eclosión de huevos de $H$. contortus expuestos al extracto etanólico elaborado con frutos de $C$. coriaria ( ${ }^{a b c}$ diferentes literales, la inhibición de la eclosión difirió entre tratamientos).
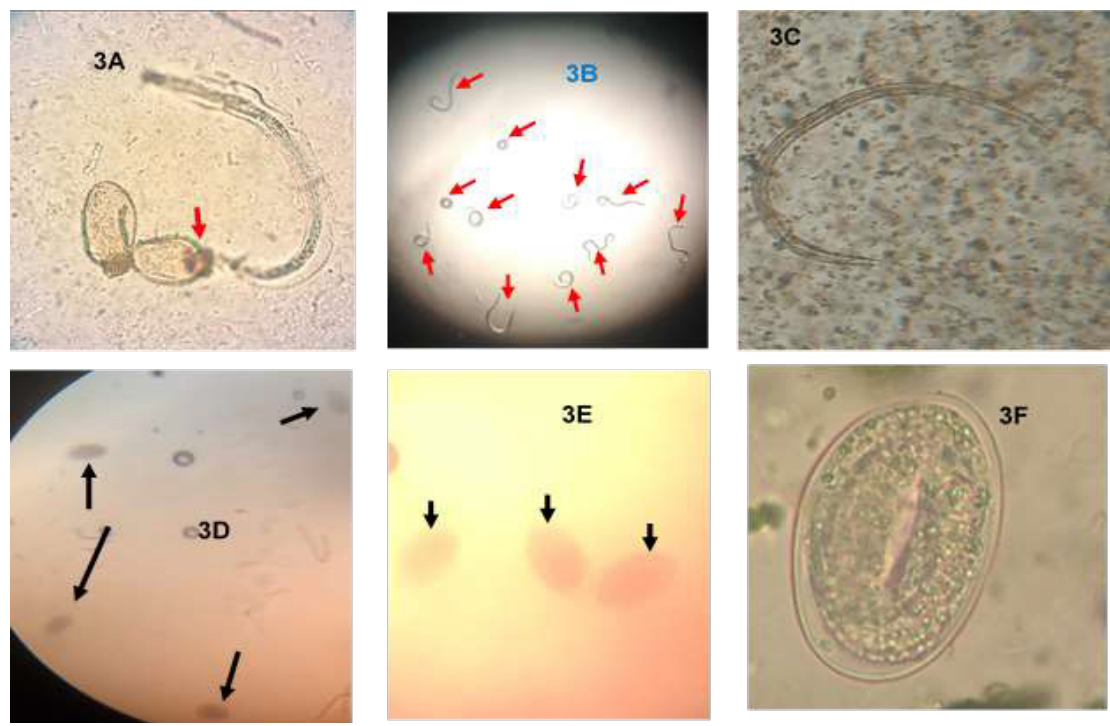

Figure 3. Microscopic images that represented the readings of the $H$. contortus eggs: (A, $B$ and $C$ ) showed the high eggs eclosion to $L 1$ larvae in the negative controls, (D, E and F) showed the remaining eggs inhibited by exposure to $C$. coriaria fruits extracts.

Figura 3. Imágenes microscópicas que representaron las lecturas de los huevos de $\boldsymbol{H}$. contortus: (A, B y C) mostraron la alta eclosión de huevos a larvas L1 en los controles negativos, (D, E y F) mostraron los huevos remanentes inhibidos por exposición a extractos de frutos de C. coriaria. 
Cassia alata and Acacia raddiana, respectively, were responsible of eggs eclosion inhibition and adult stage $H$. contortus mortality inducing, but damages in the enveloped of the eggs was not they described. Similar results were obtained by Carvalho et al. (2012), Akkari et al. (2014), Cabardo \& Portugaliza (2017) when they used ethanol solvent observed that tannins extracted polarly from several plants rich in condensed tannins, showed in studies in vitro activity to inhibit the eclosion of eggs, infective stage larvae $\left(\mathrm{L}_{3}\right)$ and caused paralysis and / or death in adult parasites. These antecedents indicated that the use of acetonic and ethanolic solvents extracted secondary polar compounds that showed activity against $H$. contortus eggs. Veloz-Garcia et al. (2004) reported as main phenolic compounds to gallic and tannic acids in the cascalote pods, in another study De Jesús-Martínez et al. (2018) reported to the gallotannins (methyl gallate) and their derivatives as primordial secondary compounds, for this reason, the effects observed against the parasite eggs in this study, could be attributed to the action of these compounds.

The lethal concentrations $\left(\mathrm{LC}_{50}\right.$ and $\mathrm{LC}_{90}$ ) of the extracts used are shown in Figure $4 \mathrm{~A}$ and $4 \mathrm{~B}$. In the acetonic extract, an $\mathrm{LC}_{50}$ of $0.23 \mathrm{mg} / \mathrm{mL}$ and $\mathrm{LC}_{90}$ of $1.04 \mathrm{mg} / \mathrm{mL}$ are observed, and for the ethanolic extract an LC $_{50}$ of 0.014 de $H$. contortus en estado adulto, pero no se describieron daños en la envoltura de los huevos. Carvalho et al. (2012), Akkari et al. (2014), Cabardo \& Portugaliza (2017) Obtuvieron resultados similares cuando utilizaron etanol como solvente, observaron que los taninos extraídos polarmente de varias plantas ricas en taninos condensados, mostraron en estudios in vitro actividad para inhibir la eclosión de huevos, larvas en estadio infectivo $\left(\mathrm{L}_{3}\right)$ y provocaron parálisis y/o muerte en parásitos adultos. Estos antecedentes indicaron que el uso de solventes acetónicos y etanólicos extrajo compuestos polares secundarios que mostraron actividad contra huevos de $H$. contortus. VelozGarcía et al. (2004) reportaron como principales compuestos fenólicos a los ácidos gálico y tánico en las vainas de cascalote, en otro estudio De Jesús-Martínez et al. (2018) reportaron a los galotaninos (galato de metilo) y sus derivados como compuestos secundarios primordiales, por esta razón, los efectos observados contra los huevos del parásito en este estudio, podrían atribuirse a la acción de éstos compuestos.

Las concentraciones letales $\left(\mathrm{LC}_{50}\right.$ y $\mathrm{LC}_{90}$ ) de los extractos utilizados se muestran en la Figura $4 \mathrm{~A}$ y $4 \mathrm{~B}$. En el extracto acetónico se observaron $\mathrm{LC}_{50}$ de $0.23 \mathrm{mg} / \mathrm{mL}$ y $L C_{90}$ de $1.04 \mathrm{mg} / \mathrm{mL}$, y para el extracto etanólico se observó una $\mathrm{LC}_{50}$ de $0.014 \mathrm{mg} / \mathrm{mL}$ y $\mathrm{LC}_{90}$ de $0.14 \mathrm{mg} / \mathrm{mL}$. Los resultados mostraron un efecto dependiente de la concentración en los diferentes extractos, sin embargo, comparativamente



A) Acetonic concentratión $(\mathrm{mg} / \mathrm{mL}$ )

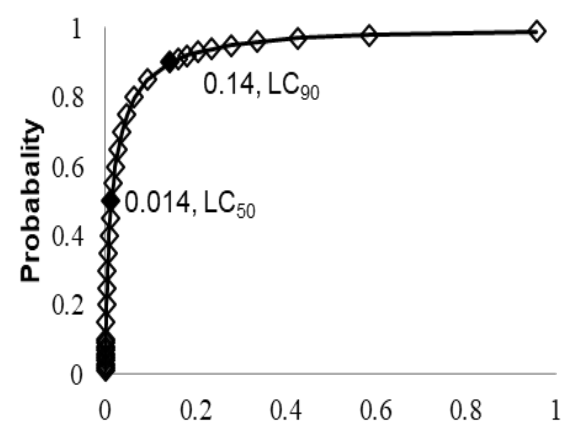

B) Ethanolic concentratión $(\mathrm{mg} / \mathrm{mL})$

Figure 4. Lethal concentrations of the acetonic (A) and ethanolic (B) extract elaborated with C. coriaria fruits on the egg eclosion inhibition of $H$. contortus.

Figura 4. Concentraciones letales del extracto acetónico (A) y etanólico (B) elaborado con frutos de $C$. coriaria sobre la inhibición de la eclosión de huevos de $\boldsymbol{H}$. contortus. 
$\mathrm{mg} / \mathrm{mL}$ and $\mathrm{CL}_{90}$ of $0.14 \mathrm{mg} / \mathrm{mL}$, are observed. The results showed a concentration-dependent effect in the different extracts, however, comparatively between the two extracts it can be seen that the lethal concentrations of the ethanolic extract were lower compared to acetonic extract, which may indicate that the polar compounds extracted of the $C$. coriaria fruits with the ethanolic solvent, turned out to be more lethal against the eggs of the parasite. Al - Rawahi et al. (2013) reported that the solubility of polyphenols is affected by the type of solvents used and their polarity, resulting in extracts with different properties despite being elaborated from the same plant. Dai \& Mumper (2010), Al-Farsi et al. (2007) observed that $100 \%$ acetone extracted flavonoid and phenolic compounds of low polarity. Ringuelet \& Viña (2013) mentioned that ethanol is a solvent of excellent solubility to extract polar compounds. The same phenomenon was observed by Castillo-Mitre et al. (2017) who reported the different effect of extracts elaborated with Acacia cochliacantha leaves using different solvents, against eggs of $H$. contortus and attributed it to polar and non-polar compounds present in the different fractions. Sánchez-Carranza et al. (2017) reported that fruits and leaves of $C$. coriaria are a rich source in condensed tannins, such as gallic acid, ethyl gallate and tannic acid, as a basis of hydrolyzable tannins, so the biological activity reported in this study could be related to these metabolites. In addition, the concentration doses used in the study were less than $9 \%$ (90 g/kg dry matter) of tannins to cause mortality in the animal (Nawab et al., 2020). Frutos et al. (2004) fed finishing lambs daily with diets added with $20.8 \mathrm{~g} /$ $\mathrm{kg}$ of dry matter, and they did not observe toxic effects or decrease in the production of the animals. ManuelPablo et al. (2020) provided daily $45 \mathrm{~g}$ of secondary compounds in the fruits of $C$. coriaria without negative effects on health, weight gain and feed conversion of the goats. Pérez, V. et al. (2011) reported symptoms such as methemoglobinemia, kidney failure, anorexia, depression and diarrhea in ruminants when they consumed tannins in the diet to higher quantities at $4400 \mathrm{mg} / \mathrm{kg}$ of body weight.

\section{Conclusions}

It is concluded that the extract elaborated with $C$. coriaria fruits in acetonic and ethanol solvents entre los dos extractos, se puede observar que las concentraciones letales del extracto etanólico fueron menores en comparación con el extracto acetónico, lo que indicó que los compuestos polares extraídos de los frutos de C. coriaria con el solvente etanólico resultaron ser más letales contra los huevos del parásito. Al-Rawahi et al. (2013) reportaron que la solubilidad de los polifenoles se ve afectada por el tipo de solventes utilizados y su polaridad, resultando en extractos con diferentes propiedades a pesar de estar elaborados a partir de la misma planta. Dai \& Mumper (2010), Al-Farsi et al. (2007) observaron que la acetona al $100 \%$ extraía compuestos flavonoides y fenólicos de baja polaridad. Ringuelet \& Viña (2013) mencionaron que el etanol es un solvente de excelente solubilidad para extraer compuestos polares. El mismo fenómeno fue observado por Castillo-Mitre et al. (2017) quienes reportaron diferente efecto de extractos elaborados con hojas de Acacia cochliacantha utilizando diferentes solventes, contra huevos de $H$. contortus y lo atribuyeron a compuestos polares y no polares presentes en las diferentes fracciones. Sánchez-Carranza et al. (2017) reportaron que frutos y hojas de $C$. coriaria son una fuente rica en taninos condensados, como ácido gálico, galato de etilo y ácido tánico, como base de taninos hidrolizables, por lo que la actividad biológica reportada en este estudio podría estar relacionada con estos metabolitos. Además, las dosis de concentración empleadas en el estudio, fueron inferiores al $9 \%$ (90 g/kg de materia seca) de taninos para causar mortalidad en el animal (Nawab et al., 2020). Frutos et al. (2004) alimentaron diariamente corderos de engorde con dietas adicionadas con $20.8 \mathrm{~g} /$ $\mathrm{kg}$ de materia seca, y no observaron efectos tóxicos ni disminución en la producción de los animales. ManuelPablo et al. (2020) proporcionaron diariamente $45 \mathrm{~g}$ de compuestos secundarios en los frutos de $C$. coriaria sin efectos negativos sobre la salud, el aumento de peso y la conversión alimenticia de las cabras. Pérez, V. et al. (2011) reportaron síntomas como metahemoglobinemia, insuficiencia renal, anorexia, depresión y diarrea en rumiantes cuando consumieron taninos en la dieta en cantidades mayores a $4400 \mathrm{mg} / \mathrm{kg}$ de peso corporal.

\section{Conclusiones}

Se concluye que el extracto elaborado con frutos de C. coriaria en solventes acetónicos y etanólicos inhibe la 
eclosion inhibits $H$. contortus eggs, so it could be an option in the treatment of nematodes in small ruminants, however, it requires more research as antiparasitic for direct and reliable use in animals. The effect on the eggs eclosion inhibition of the parasite was different between the extracts and was attributed to the solvent used because it was the same arboreal fruit. The findings in this study require additional investigations for the identification of the compounds responsible for the EEI, by means of studies of identification of bioactive compounds by high-performance liquid chromatography (HPLC).

\section{Conflicts of Interest}

The authors declare that there are no conflicts of interest regarding the publication of this paper.

\section{Acknowledgements}

Part of this work was supported by INIFAP (project SIGI: 8215734475). This research forms part of the Master's thesis of MVZ Xochitl de Jesús Martínez under the direction of Dr Jaime Olivares-Pérez and Dr Agustín Olmedo-Juárez. eclosión de huevos de $H$. contortus, por lo que podría ser una opción en el tratamiento de nematodos en pequeños rumiantes, sin embargo, requiere más investigación como antiparasitario para uso directo y confiable en animales. El efecto sobre la inhibición de la eclosión de huevos del parásito fue diferente entre los extractos y se atribuyó al solvente utilizado, por tratarse del mismo fruto arbóreo. Los hallazgos de este estudio requieren investigaciones adicionales para la identificación de los compuestos responsables de la EEI, mediante estudios de identificación de compuestos bioactivos mediante cromatografía líquida de alta resolución (HPLC).

\section{Conflictos de interés}

Los autores declaran que no existen conflictos de intereses con respecto a la publicación de este artículo.

\section{Agradecimientos}

Parte de este trabajo fue apoyado por INIFAP (proyecto SIGI: 8215734475). Esta investigación forma parte de la tesis de maestría de MVZ Xochitl de Jesús Martínez bajo la dirección del Dr. Jaime Olivares-Pérez y el Dr. Agustín Olmedo-Juárez.

\section{References}

Ademola, I. O., \& Eloff, J. N. (2011). Ovicidal and larvicidal activity of Cassia alata leaf acetone extract and fractions on Haemonchus contortus: In vitro studies. Pharmaceutical Biology, 49(5), 539-544. https://doi.org/10.3109/1388 $\underline{0209.2010 .526948}$

Akkari, H., Rtibi, K., B'chir, F., Rekik, M., Darghouth, M.A., \& Gharbi, M. (2014). In vitro evidence that the pastoral Artemisia campestris species exerts an anthelmintic effect on Haemonchus contortus from sheep. Veterinary Research Communications, 38, 249-255. https://doi.org/10.1007/s11259-014-9609-y

Al-Farsi, M., Alasalvar, C., Al-Abid, M., Al-Shoaily, K., Al-Amry, M., \& Al-Rawahy, F. (2007). Compositional and functional characteristics of dates, syrups, and their by-products. Food and Chemistry, 104(3), 943-947. http://dx.doi. org/10.1016/i.foodchem.2006.12.051

AlRawahi, A. S., Rahman, M. S., Guizani, N., \& Essa, M. M. (2013). Chemical composition, water sorption isotherm, and phenolic contents in fresh and dried pomegranate peels. Journal Drying Technology, 31(3), 257-263. https://doi. org/10.1080/07373937.2012.710695

Baltrušis, P., Komáromyová, M., Várady, M., Samson-Himmelstjerna, G., \& Johan Höglund, J. (2020). Assessment of the F200Y mutation frequency in the $\beta$ tubulin gene of Haemonchus contortus following the exposure to a discriminating concentration of thiabendazole in the egg hatch test. Experimental Parasitology, 217, 107957. https://doi.org/10.1016/j.exppara.2020.107957

Cabardo, D. E., \& Portugaliza, H. P. (2017). Anthelmintic activity of Moringa oleifera seed aqueous and ethanolic extracts against Haemonchus contortus eggs and third stage larvae. International Journal of Veterinary Science and Medicine, 5(1), 30-34. https://doi.org/10.1016/j.ijvsm.2017.02.001 
Canul-Ku, H. L., Rodríguez-Vivas, R. I., Torres-Acosta, J. F. J., Aguilar- Caballero, A. J., Pérez-Cogollo, L. C., \& Ojeda-Chi, M. M. (2012). Prevalence of cattle herds with ivermectin resistant nematodes in the hot sub-humid tropics of Mexico. Veterinary Parasitology, 183(3-4), 292-298. https://doi.org/10.1016/j.vetpar.2011.07.029

Carvalho, C. O., Chagas, A. C. S., Cotinguiba, F., Furlanc, M., Brito, L. G., Chaves, F. C. M., Stephan, M. P., Bizzo, H. R., \& Amarante, A. F. T. (2012). The anthelmintic effect of plant extracts on Haemonchus contortus and Strongyloides venezuelensis. Veterinary Parasitology, 183(3-4), 260- 268. https://doi.org/10.1016/j.vetpar.2011.07.051

Castillo-Mitre, G. F., Olmedo-Juárez, A., Rojo-Rubio, R., Cortázar-González, M., Mendoza-de Gives, P., Hernández-Beteta, E. E., Reyes-Guerrero, D. E., López- Arellano, M. E., Vázquez-Armijo, J. F., Ramírez-Vargas, G., \& Zamilpa, A. (2017). Caffeoyl and coumaroyl derivatives from Acacia cochliacantha exhibit ovicidal activity against Haemonchus contortus. Journal of Ethnopharmacology. 204, 125-131. https://doi.org/10.1016/i.jep.2017.04.010

Dai, J., \& Mumper, R. J. (2010). Plant phenolics: extraction, analysis and their antioxidant and anticancer properties. Molecules, 15(10), 7313-7352. https://doi.org/10.3390/molecules15107313

De Jesús-Martínez, X., Olmedo-Juárez, A., Olivares-Pérez, J., Zamilpa, A., Mendoza-De Gives, P., López-Arellano, M. E., Rojas-Hernández, S., Villa-Mancera, A., Camacho-Díaz, L. M., \& Cipriano-Salazar, M. (2018). In Vitro Anthelmintic Activity of Methanolic Extract from Caesalpinia coriaria J. Willd Fruits against Haemonchus contortus Eggs and Infective Larvae. BioMed Research International, 2018, 7375693. https://doi.org/10.1155/2018/7375693

Delgado, A., Núñez, O., Aguilera, V. L., Palacios, D., Salas, R. J., Berbert, G., González, M., \& Fernández, N. (2016). Acción ovicida in vitro del extracto hidro-alcoholico crudo de la semilla de Pouteria sapota (mamey colorado) contra huevos de Haemonchus contortus. Primer reporte. Revista de Producción Animal, 28(2-3), 51-54. http://scielo. sld.cu/scielo.php?script=sci arttext\&pid=S2224-79202016000200007

Delgado-Núñez, E. J., Zamilpa, A., González-Cortazar, M., Olmedo-Juárez, A., Cardoso-Taketa, A., Sánchez-Mendoza, E., Tapia-Maruri, D., Salinas-Sánchez, D. O., \& Mendoza-de Gives, P. (2020) Isorhamnetin: A Nematocidal Flavonoid from Prosopis laevigata Leaves Against Haemonchus contortus Eggs and Larvae. Biomolecules, 10(5), 773. https://doi.org/10.3390/biom10050773

Ehsan, M., Hu, R. S., Liang, Q. L., Hou, J. L., Song, X., Yan, R., Zhu, X. Q., \& Li, X. (2020). Advances in the Development of Anti-Haemonchus contortus Vaccines: Challenges, Opportunities, and Perspectives. Vaccines, 8(3), 1-18. http:// dx.doi.org/10.3390/vaccines8030555

Frutos, P., Raso, M., Hervás, G., Mantecón, A. R., Pérez, V., \& Giráldez, F. J. (2004). Is there any detrimental effect when a chestnut hydrolysable tannin extract is included in the diet of finishing lambs?. Animal Research, 53(2), 127-136. https://doi.org/10.1051/animres:2004001

García-Ortiz, N., Aguilar-Marcelino, L., Mendoza-de-Gives, P., López-Arellano, M. E., Bautista-Garfias, C. R., \& GonzálezGarduño, R. (2015). In vitro predatory activity of Lasioseius penicilliger (Arachnida: Mesostigmata) against three nematode species: Teladorsagia circumcincta, Meloidogyne sp. and Caenorhabditis elegans. Veterinaria México, 2(1), 1-8. http://dx.doi.org/10.21753/vmoa.2.1.340

Kaplan, M. R., \& Vidyashankar, N. A. (2012). An inconvenient truth: Global worming and anthelmintic resistance. Veterinary Parasitology, 186(1-2), 70-78. https://doi.org/10.1016/j.vetpar.2011.11.048

Laca-Megyesi, Š., Königová, A., Babják, M., Molnár, L., Rajský, M., Szestáková,E., Major, P., Soroka, J., Urda-Dolinská, M., Komáromyová, M., \& Várady, M. (2020). Wild ruminants as a potential risk factor for transmission of drug resistance in the abomasal nematode Haemonchus contortus. European Journal of Wildlife Research, 66, 9. https://doi.org/10.1007/s10344-019-1351-x

León-Castro, Y., Olivares-Pérez, J., Rojas-Hernández, S., Villa-Mancera, A., Valencia-Almazán, M. T., Hernández-Castro, E., Córdova-Izquierdo A., \& Jiménez-Guillén R. (2015). Chemical composition of three tree fodders and effect in control Haemonchus contortus and change of body weight in kids. Ecosistemas y Recursos Agropecuarios, 2(5), 193-201. https://www.redalyc.org/pdf/3586/358638159007.pdf

Manuel-Pablo, A., Elghandour, M. M. Y., Olivares-Pérez, J., Rojas-Hernández, S., Cipriano-Salazar, M., Cruz-Lagunas, B., \& Camacho-Diaz, L. M. (2020) Productive performance, rumen fermentation and carcass yield of goats supplemented with cascalote fruit (Caesalpinia coriaria J. Wild.). Agroforestry Systems, 94, 1381-1391. https:// doi.org/10.1007/s10457-018-0312-9 
Muñiz-Lagunés, A., González-Garduño, R., López-Arellano, M. E., Ramírez-Valverde, R., Ruíz-Flores, A., García-Muñiz, G., Ramírez-Vargas, G., Mendoza-de Gives, P., \& Torres Hernández, G. (2015). Anthelmintic resistance in gastrointestinal nematodes from grazing beef cattle in Campeche State, Mexico. Tropical Animal Health and Production, 47, 1049-1054. https://doi.org/10.1007/s11250-015-0826-3

Nawab, A., Tang, S., Gao, W., Li, G., Xiao, M., An, L., Wu J., \& Liu, W. (2020) Tannin Supplementation in animal feeding; mitigation strategies overcome the toxic effects of tannins on animal health: A Review. Journal of Agricultural Science, 12(4), 217-230. https://doi.org/10.5539/jas.v12n4p217

Olivares, P. J., Gutiérrez, S. I., Rojas, H. S., Valencia, A. M. T., Míreles, M. E. J., \& Córdova, I. A. (2012). Seasonal prevalence of Strongyle in Creole goats of the Tierra Caliente region, State of Guerrero, México. Research Opinions in Animal and Veterinary Sciences, 2(3), 216-220. http://www.roavs.com/pdf-files/lssue 3 2012/216-220.pdf

Olmedo, J. A., Rojo, R. R., Arece, G. J., Mohamed, A. Z. S., Kholif, E. A., \& Morales, A. E. (2014). In vitro of Pithecellobium dulce and Lysiloma acapulcensis on the exogenous development of gastrointestinal strongyles in sheep. Italian Journal of Animal Science. 13(4), 303-307. https://doi.org/10.4081/ijas.2014.3104

Pérez- Pérez, C., Hernández-Villegas, M. M., Cruz- Burelo, P., Bolio-López, G. I., \& Hernández-Bolio, G. I. (2014). Efecto antihelmitico in vitro del extracto metanólico de hojas de Gliricidia sepium contra nematodos gastrointestinales de ovinos. Tropical and subtropical agroecosystems, 17(1), 105-111. https://www.redalyc. org/pdf/939/93930735013.pdf

Pérez, V., Doce, R. R., García-Pariente, C., Hervás, G., Carmen Ferreras, M., Mantecón, Á. R., \& Frutos, P. (2011). Oak leaf (Quercus pyrenaica) poisoning in cattle. Research in Veterinary Science, 91(2), 269-277. https://doi. org/10.1016/j.rvsc. 2010.12.015

Poné, J. W., Florence, K. T., Mbida, M., Tedonkeng, E. P., \& Bilong C. F. B. (2011). In vitro activities of acetonic extracts from leaves of three forage legumes (Calliandra calotyrsus, Gliricidia sepium and Leucaena diversifolia) on Haemonchus contortus. Asian Pacific Journal of Tropical Medicine, 4(2), 125-128. https://doi.org/10.1016/ $\underline{\mathrm{s} 1995-7645(11) 60051-5}$

Ringuelet, J. A., \& Viña, S. Z. (2013). Productos Naturales Vegetales. Universidad Nacional de La Plata - Editorial de la Universidad de La Plata. Pag. 16. https://doi.org/10.35537/10915/27885

Sánchez-Carranza, J. N., Álvarez, L., Marquina-Bahena, S., Salas-Vidal, E., Cuevas, V., Jiménez, E. W., Rafael, A., Veloz, G., Carraz, M. and González-Maya, L. (2017). Phenolic compounds isolated from Caesalpinia coriaria induce S and G2/M phase cell cycle arrest differentially and trigger cell death by interfering with microtubule dynamics in cancer cell lines. Molecules, 22(4), 666. https://doi.org/10.3390/molecules22040666

SAS. (2002). Statistical Analysis System, Institute SAS/STAT User's Guide. Version 8, 6th Edition, SAS Institute, Cary, $112 \mathrm{p}$ Veloz-García, R. A., Martin-Martínez, R., Veloz-Rodríguez, R., Muñoz-Sánchez, C. I., Guevara-Olvera, L., Miranda-López, R., González-Chavira, M. M., Torres-Pacheco, I., Guzmán-Maldonado, S. H., Cardador-Martínez, A., Loarca-Piña, L., \& Guevara-González, R. G. (2004). Antimutagenic and antioxidant activities of cascalote (Caesalpinia cacalaco) phenolics. Journal of the Science of Food and Agriculture, 84(13), 1632-1638. https://doi.org/10.1002/jsfa.1852

Von Son-de Fernex, E., Alonso-Díaz, M. A., Mendoza-de-Gives, P., Valles-de la Mora, B., González-Cortazar, M., Zamilpa, A., \& Castillo-Gallegos, E. (2015). Elucidation of Leucaena leucocephala anthelmintic-like phytochemicals and the ultrastructural damage generated to eggs of Cooperia spp. Veterinary Parasitology, 214 (1-2),89-95. https:// doi.org/10.1016/j.vetpar.2015.10.005

Zabré, G., Kaboré, A., Bayala, B., Katiki, L. M., Costa-Júnior, L. M., Tamboura, H. H., Adrien, M.G., Belem, A. M. G., Abdalla, A. L., Niderkorn V., Hoste, H., \& Louvandini, H. (2017). Comparison of the in vitro anthelmintic effects of Acacia nilotica and Acacia raddiana. Parasite. 24, 44. https://doi.org/10.1051/parasite/2017044

Zapata, S. R., Velásquez, V. R., Herrera, O. L. V., Ríos, O. L., \& Polanco, E. D. N. (2016). Prevalencia de Nematodos Gastrointestinales en Sistemas de Producción Ovina y Caprina bajo Confinamiento, Semiconfinamiento y Pastoreo en Municipio de Antoquia, Colombia. Revista de Investigaciones Veterinarias del Perú, 27(2), 344354. https://dx.doi.org/10.15381/rivep.v27i2.11647 